\title{
Epidemiology of toxoplasmosis*
}

\author{
By D. G. FLECK \\ Public Health Laboratory, Swansea
}

(Received 16 August 1962)

\section{INTRODUCTION}

Interest in toxoplasmosis has been stimulated over the last few years by the finding that this infection is widespread biologically as well as geographically. Serious clinical illness is however uncommon. Definitive diagnosis depends on isolation of the causative organism by inoculation of biopsy material into animals known to be free from toxoplasma infection. Recognition of the vegetative form of the organism is difficult histologically.

Other workers (Plaut, 1946; Tomlinson, 1945) have described toxoplasma-like organisms seen in patients dying of various diseases and accidents. It is well accepted that asymptomatic toxoplasma infection occurs.

The ability of Toxoplasma gondii to produce chorioretinitis and lymphadenitis is now well documented (Perkins, 1961; Siim, 1956). Suggestions are made from time to time that other syndromes may be due to toxoplasma infection. Thalhammer (1962), for example, has suggested that the frequency of infection is much greater in cases of epilepsy and mental defect than in the normal human population.

The first part of this investigation consisted in comparing the incidence of antibody in sera from a normal population with that in sera sent from suspected cases of toxoplasmosis. The normal population consisted of routine admissions to a children's hospital in which toxoplasmosis was not suspected and of children undergoing a survey for poliomyelitis antibody. Adult sera were obtained from the Welsh Regional Blood Transfusion Service.

In addition, seventy-two cases of suspected cat-scratch fever have been examined for toxoplasma antibody. Details of contact with cats and whether a scratch was sustained were recorded where possible.

Domestic pets have frequently been suggested as possible vectors of toxoplasma infection. Cats in contact with human cases have been found to be infected (Jones, Eyles \& Gibson, 1957), but whether the cats or the human cases were the originators of the infection was unknown. A source of infection common to both cats and humans may have been involved. Sera from cat-scratch fever cases were examined by Jacobs (cited by Armstrong \& MacMurray, 1953) with negative results.

Perkins (1961) examined cases of uveitis and found that only in patients having contact with cats was the percentage of positive dye tests greater than the percentage of negative dye tests and then not significantly so.

* Part of this work was submitted as a thesis for the Degree of M.D. of the University of London. 


\section{MATERIALS AND METHODS}

All sera were stored at $-20^{\circ} \mathrm{C}$. Dye tests were performed on sera inactivated at $56^{\circ} \mathrm{C}$. for $\frac{1}{2} \mathrm{hr}$. according to the method used by Beverley \& Beattie (1952), which was similar to that of Sabin \& Feldman (1948).

\section{RESULTS}

Table 1 shows that only in disorders of the eyes was the proportion of positive sera from suspected cases of toxoplasmosis significantly higher than normal; though for cases of choroiditis in the age group 51-60, the proportion was only just significant at the $5 \%$ level. Cases of mesenteric adenitis, mental defect and epilepsy gave proportions significantly lower than expected. Although disorders of the reticulo-endothelial system showed a percentage higher than normal throughout all ages, this never reached a significant level.

Table 1. Proportion of sera positive by the dye test at 1/16 or more (Nov. 1959-Nov. 1960)

(Figures in parentheses indicate percentages of sera positive at 1/16 or more.)

\begin{tabular}{|c|c|c|c|c|c|c|}
\hline $\begin{array}{l}\text { Age in } \\
\text { years }\end{array}$ & $\begin{array}{l}\text { Reticulo- } \\
\text { endothelial } \\
\text { system }\end{array}$ & $\begin{array}{l}\text { Central } \\
\text { nervous } \\
\text { system }\end{array}$ & Jaundice & $\begin{array}{l}\text { Cardio- } \\
\text { vascular } \\
\text { system }\end{array}$ & Choroiditis & Uveitis \\
\hline $0-10$ & $32 / 288(11)$ & $9 / 98(9)$ & $3 / 26(12)$ & $0 / 11(0)$ & $24 / 38(63)$ & $8 / 36(22)$ \\
\hline $11-20$ & $30 / 160(19)$ & $0 / 2$ & 2/6 (33) & $1 / 10(10)$ & $54 / 80(68)$ & $18 / 63(29)$ \\
\hline $21-30$ & $25 / 104(24)$ & $5 / 12(42)$ & 0 & $5 / 12(42)$ & $86 / 144(60)$ & $44 / 101(44)$ \\
\hline $31-40$ & $25 / 76(33)$ & $5 / 13(38)$ & 0 & $5 / 11(45)$ & $75 / 118(64)$ & $43 / 106(41)$ \\
\hline $41-50$ & $17 / 35(49)$ & $1 / 3(33)$ & $1 / 1(100)$ & $7 / 17(41)$ & $39 / 67(58)$ & $33 / 91(36)$ \\
\hline $51-60$ & $10 / 29(34)$ & $6 / 8(75)$ & $1 / 2(50)$ & $3 / 19(16)$ & $24 / 48(50)$ & $26 / 73(36)$ \\
\hline Totals & $139 / 692(20)$ & $26 / 136(19)$ & $7 / 35(20)$ & $21 / 80(26)$ & $302 / 495(61)$ & $172 / 470(37)$ \\
\hline $\begin{array}{l}\text { Age in } \\
\text { years }\end{array}$ & $\begin{array}{l}\text { Other } \\
\text { eye } \\
\text { lesions }\end{array}$ & $\begin{array}{l}\text { Mesenteric } \\
\text { adenitis }\end{array}$ & Epilepsy & $\begin{array}{c}\text { Mental } \\
\text { defect }\end{array}$ & $\begin{array}{l}\text { Hydro- } \\
\text { cephalus }\end{array}$ & $\begin{array}{c}\text { Normal } \\
\text { population }\end{array}$ \\
\hline $0-10$ & $4 / 38(11)$ & $0 / 17$ & $10 / 160(6)$ & $1 / 114(1)$ & $5 / 38(13)$ & $15 / 180(8)$ \\
\hline $11-20$ & $7 / 22(32)$ & $1 / 10(10)$ & $0 / 14$ & $1 / 7(14)$ & $0 / 1$ & $13 / 94$ (14) \\
\hline $21-30$ & $9 / 22(41)$ & 0 & $1 / 3(33)$ & $2 / 2(100)$ & 0 & $15 / 80(19)$ \\
\hline $31-40$ & $6 / 15(40)$ & 0 & $2 / 4(50)$ & 0 & $1 / 2(50)$ & $20 / 80(25)$ \\
\hline $41-50$ & $6 / 16(38)$ & 0 & 0 & 0 & 0 & $28 / 80(35)$ \\
\hline $51-60$ & $11 / 16(69)$ & 0 & 0 & 0 & 0 & $23 / 73(32)$ \\
\hline Totals & $43 / 129(33)$ & $1 / 27(4)$ & $13 / 181(7)$ & $4 / 123(3)$ & $6 / 41(15)$ & $114 / 587(19)$ \\
\hline
\end{tabular}

Later investigations measuring the antibody content down to $1 / 4$ for the age group 0-10 years were made during 1961. In Table 2 the results show a fall in incidence of sera positive at $1 / 4$ or more after 6 months of age. This is due to the disappearance of passively transferred maternal antibody. A control group of the normal population at 0-6 months was not included as this would merely have reflected the antibody titres in the mothers. After 6 months the proportion of sera positive at $1 / 4$ or more in the dye test is significantly higher than normal only in cases of choroiditis.

Table 3 analyses the cases of suspected cat-scratch fever according to their 
possession of toxoplasma antibody. Although the numbers are small the cases showing toxoplasma antibody are not significantly greater than in the normal population. Of the seventy-two cases studied, forty-four gave a definite history of being scratched by a cat; of these, eight showed toxoplasma antibody titres of $1 / 16$ or more in the dye test. Of the fifty-nine with a definite history of contact with cats, ten showed antibody titres of $1 / 16$ or more.

Table 2. Proportion of sera positive by the dye test at $1 / 4$ or more (Nov. 1960-Nov. 1961)

(Figures in parentheses indicate percentages of sera positive at $1 / 4$ or more.)

\begin{tabular}{|c|c|c|c|c|c|}
\hline Age & $\begin{array}{l}\text { Reticulo- } \\
\text { endothelial } \\
\text { system }\end{array}$ & $\begin{array}{c}\text { Central } \\
\text { nervous } \\
\text { system }\end{array}$ & Jaundice & Choroiditis & $\begin{array}{l}\text { Other } \\
\text { eye } \\
\text { lesions }\end{array}$ \\
\hline $\begin{array}{l}0-6 \text { months } \\
7 \text { months to } 5 \text { years } \\
10 \text { years }\end{array}$ & $\begin{array}{l}0 / 7 \\
11 / 55(20) \\
23 / 129(18)\end{array}$ & $\begin{array}{l}7 / 19(37) \\
2 / 21(10) \\
3 / 11(27)\end{array}$ & $\begin{array}{l}13 / 43(30) \\
0 / 2 \\
1 / 4(25)\end{array}$ & $\begin{array}{l}0 / 2 \\
7 / 16(44) \\
12 / 19(63)\end{array}$ & $\begin{array}{l}2 / 9(22) \\
1 / 23(4) \\
1 / 14(7)\end{array}$ \\
\hline Totals & $34 / 191(18)$ & $12 / 51(24)$ & $14 / 49(29)$ & $19 / 37(51)$ & $4 / 46(9)$ \\
\hline $\begin{array}{l}\text { Totals excluding } 0-6 \\
\text { months }\end{array}$ & $34 / 184(18)$ & $\begin{array}{c}5 / 32(16) \\
\text { Mental } \\
\text { defect }\end{array}$ & $\begin{array}{c}\text { 1/6 (17) } \\
\text { Hydro- } \\
\text { cephalus }\end{array}$ & $\begin{array}{c}19 / 35(54) \\
\text { Normal } \\
\text { population }\end{array}$ & $2 / 37(5)$ \\
\hline $\begin{array}{l}0-6 \text { months } \\
7 \text { months to } 5 \text { years } \\
10 \text { years }\end{array}$ & $\begin{array}{l}15 / 49(31) \\
8 / 100(8) \\
3 / 34(9)\end{array}$ & $\begin{array}{l}2 / 15(13) \\
4 / 73(5) \\
3 / 20(15)\end{array}$ & $\begin{array}{l}19 / 51(37) \\
1 / 17(6) \\
1 / 2(50)\end{array}$ & $\begin{array}{c}\overline{-} \\
6 / 79(8) \\
14 / 87(16)\end{array}$ & \\
\hline Totals & $26 / 183(14)$ & $9 / 108(8)$ & $21 / 70(30)$ & $20 / 166(12)$ & \\
\hline $\begin{array}{l}\text { Totals excluding } 0-6 \\
\text { months }\end{array}$ & $11 / 134(8)$ & $7 / 93(8)$ & $2 / 19(11)$ & $20 / 166(12)$ & \\
\hline
\end{tabular}

Table 3. Cases of suspected cat-scratch fever tested for toxoplasma antibody and compared with a normal population

(Figures in parentheses indicate percentages of sera positive at $1 / 16$ or more.)

$\begin{array}{ccccc}\begin{array}{c}\text { Age in } \\ \text { years }\end{array} & \begin{array}{c}\text { No. }+1 / 16 \\ \text { or more }\end{array} & \begin{array}{c}\text { No. } \\ \text { negative }\end{array} & \begin{array}{c}\text { Proportion }+1 / 16 \\ \text { or more }\end{array} & \begin{array}{c}\text { Proportion of normal } \\ \text { population }+1 / 16 \\ \text { or more }\end{array} \\ 0-10 & 3 & 27 & 3 / 30(10) & 15 / 180(8) \\ 11-20 & 1 & 13 & 1 / 14(7) & 13 / 94(14) \\ 21-30 & 1 & 12 & 1 / 13(8) & 15 / 80(19) \\ 31-40 & 2 & 2 & 2 / 4(50) & 20 / 80(25) \\ 41-50 & 4 & 1 & 4 / 5(80) & 28 / 80(35) \\ 60+ & 2 & 4 & 2 / 6(33) & 23 / 73(32) \\ \text { Totals } & 13 & 59 & 13 / 72(18) & 114 / 587(19)\end{array}$

In only three cases was the dye test titre greater than $1 / 256$. In one of these the dye test in the serum from the cat responsible for the scratch was negative; in another the dye test in the cat was positive at only $1 / 4$. In the third case there was no definite history of scratch from the cat with which the case had been in contact. Serum from the cat could not be obtained.

It is suggested that cat scratch or contact must be an unlikely method of contracting toxoplasmosis. 


\section{DISCUSSION}

Antibody to Toxoplasma gondii in low concentration is found in many areas of the world. This organism produces much latent infection. That it produces very much oligo-symptomatic infection is disputable.

The material presented above suggests that mental defectives and epileptics are no more likely to suffer from toxoplasmosis than the rest of the community, at least in the south of England and Wales. These results differ from those of Thalhammer (1962) but agree with those of other workers.

Feldman (1958) found congenital toxoplasmosis not to be unduly frequent in epileptic children. Cook \& Derrick (1961) in Australia found that their results were in accord with those of Feldman as regards epileptic children and that toxoplasmosis was, at most, only a rare cause of congenital mental deficiency. Their results resembled those of Burkinshaw, Kirman \& Sorsby (1953), who found that only $4.4 \%$ of certified mental defectives under 15 years, in London, reacted to the toxoplasmin skin test.

Of the cases of lymphadenopathy and reticulo-endothelial disorder examined, toxoplasma infection would not seem to be a common cause. It is however, a well established one, as is shown by previous workers, and by the fact that four strains of $T$. gondii have been isolated in this laboratory from twelve lymph gland biopsies. The biopsies were in cases in which the dye test titres were more than 1/512. A dye test is indicated in a young person with lymphadenopathy, especially when the Paul-Bunnell test is negative.

Little progress has been made in elucidating the mode of transfer of $T$. gondii to man, but the investigation reported suggests that cats are unlikely vectors, at any rate by scratching.

\section{SUMMARY}

Sera sent for routine examination from hospitals in south England and Wales were examined and compared with sera from the normal population. Choroiditis was the only disease syndrome showing a significantly higher proportion of positives than normal.

Cats were shown to be unlikely vectors of toxoplasma infection, at least by scratching.

Thanks are due to many pathologists throughout the country who sent sera and details of cases. Normal children's sera were kindly sent to me by Dr A. D. Evans of the Public Health Laboratory, Cardiff, Dr A. Macrae, Colindale, and Dr Margaret Wilson, Public Health Laboratory, Sheffield. Dr Patricia Bradstreet kindly sent me details of requests for cat scratch antigen.

Mr R. Payne carried out the dye tests and Mr H. J. Godwin of the Department of Pure Mathematics, University College of Swansea, kindly checked the statistical calculations.

Many thanks are due to Dr R. J. Drummond and his staff of the National Blood Transfusion Service (Welsh Region) for supplying the sera from blood donors. 


\section{REFERENCES}

Armstrong, C. \& MacMurray, F. G. (1953). J. Amer. med. Ass. 151, 1103.

Beverley, J. K. A. \& Beattie, C. (1952). J.clin. Path., 5, 350.

Burkinshaw, J., Krrman, B. H. \& Sorsby, A. (1953). Brit. med. J. i, 702.

Cook, I. \& Derrick, E. H.(1961). Aust. Ann. Med. 10, 137.

Feldman, H. A. (1958). Paediatrics, 22, 559.

Jones, F. E., Eyles, D. E. \& Gibson, C. L. (1957). Amer. J. trop. Med. Hyg. 6, 820. Perkins, E. S. (1961). Uveitis and Toxoplasmosis, p. 110. London: Churchill Ltd.

Plaut, A. (1946). Amer. J. Path. 22, 427.

Sabin, A. B. \& Feldman, H. A. (1948). Science, 108, 660.

Sirm, J. Chr. (1956). Ann. N.Y. Acad. Sci. 64, 185

Thalmammer, O. (1962). Lancet, i, 23.

Tomlinson, W. J. (1945). Amer. J. clin. Path. 15, 123. 